\title{
KONFLIK KEWENANGAN ABSOLUT PENGADILAN AKIBAT PENENTUAN POKOK SENGKETA YANG BERBEDA
}

\author{
Kajian Putusan Nomor 454/PDT.G/2005/PA.LMG dan Nomor 163/PDT.G/2008/PT.SBY
}

\section{CONFLICT OF COURT'S ABSOLUTE AUTHORITY DUE TO DETERMINATION OF DIFFERENT SUBJECT OF DISPUTE}

\author{
An Analysis of Court Decision Number 454/PDT.G/2005/PA.LMG \\ and Number 163/PDT.G/2008/PT.SBY
}

\author{
Harijah Damis \\ Pengadilan Agama Lamongan \\ J1. Panglima Sudirman No. 378 B Lamongan 62291 \\ E-mail: harijahdamis@gmail.com
}

Naskah diterima: 27 Januari 2017; revisi: 13 November 2017; disetujui 27 Maret 2018

http://dx.doi.org/10.29123/jy.v11i1.20

\begin{abstract}
ABSTRAK
Putusan Nomor 454/PDT.G/2005/PA.LMG menarik untuk dianalisis karena dua hal. Pertama, terkait dengan titik singgung kewenangan mengadili sengketa hibah/waris pada dua lembaga peradilan dengan adanya Putusan Nomor 163/PDT.G/2008/PT.SBY, dan kedua, tidak ada amar bersifat condemnatoir pada putusan tersebut. Adanya dua putusan pada dua lembaga peradilan yang saling berlawanan terhadap objek dan subjek yang sama menyebabkan penyelesaian perkara ini belum berakhir hingga kini dan tidak adanya kepastian hukum bagi masyarakat pancari keadilan walaupun perkara ini telah melalui proses panjang (sejak tahun 2005 sampai saat ini di tahun 2017). Untuk menganalisis masalah tersebut, ada dua masalah pokok yang diangkat dalam penelitian ini. Apakah pertimbangan hukum pengadilan negeri dalam menerima dan mengadili perkara ini dapat dibenarkan menurut kompetensi absolut yang dimilikinya? Apakah asas ne bis in idem dapat diterapkan dalam hal pengadilan negeri mengadili perkara yang sudah diputus oleh pengadilan agama? Adapun metode yang digunakan dalam penelitian
\end{abstract}

ini adalah metode penelitian hukum normatif. Hasil penelitian menunjukkan bahwa pokok sengketa yang harus diangkat oleh pengadilan negeri maupun pengadilan agama adalah keabsahan hibah dengan jalan pewarisan. Asas ne bis in idem tidak dapat diterapkan oleh pengadilan negeri dalam mengadili perkara tersebut karena putusan pengadilan agama belum berkekuatan hukum tetap.

Kata kunci: hibah, waris, kewenangan, peradilan, pokok sengketa.

\section{ABSTRACT}

Court Decision Number 454/PDT.G/2005/PA.LMG is thought-provoking to examine for two things. Firstly, it is related to the authority tangency point in adjudicating grant/heir disputes at two judicial institutions with the Court Decision Number 163/PDT.G/2008/PT.SBY, and secondly, the ruling of the decision is not condemnatory. Two decisions on two opposing jurisdictions against the same object and subject cause the case to remain unresolved until now. There is no legal certainty for the 
justice seekers, although the case has gone through a long process (since 2005 until now in 2017). To analyze the problem, there are two main issues elaborated in this study. Could the legal considerations of a district court in accepting and adjudicating cases be justified according to their absolute competence? Could the principle of nebis in idem be applied in the case of a district court adjudicating a case which has been decided by a religious court? This research uses normative legal research methods. The results of the study indicate that the subject of the dispute that should be examined by the district court as well as the religious court is the validity of the grant through inheritance. The district court cannot apply the nebis in idem principle in the proceedings as the decision of the religious court has not been permanently enforced.

Keywords: grant, inheritance, authority, judiciary, subject matter dispute.

\section{PENDAHULUAN}

\section{A. Latar Belakang}

Hibah merupakan salah satu bentuk peralihan dan perolehan harta dari seseorang kepada orang lain selain jual beli, warisan, wasiat, dan hadiah. Harta yang dihibahkan haruslah harta milik pemberi hibah, sehingga hibah sangat terkait dengan cara perolehan harta milik pemberi hibah. Salah satu bentuk peralihan harta yang selalu terkait dengan hibah adalah pewarisan. Pada umumnya hibah yang kemudian menjadi sengketa di pengadilan adalah hibah yang terkait dengan harta warisan. Hal ini disebabkan harta yang dihibahkan masih terkait dengan hak ahli waris lain atau terjadi perbedaan sistem hukum mana yang digunakan dalam masyarakat.

Perbedaan sistem hukum yang berpengaruh khususnya di Indonesia, juga sangat berpengaruh pada besarnya porsi bagian masing-masing ahli waris, termasuk pada perbedaan golongan yang berhak menerima harta warisan maupun ahli waris yang tertutup menerima harta warisan pewaris karena terhalang oleh ahli waris yang lebih dekat hubungan kekerabatannya. Di Indonesia, hingga kini masih menganut pluralisme sistem hukum, yakni sistem hukum Islam, sistem hukum adat, dan sistem hukum perdata barat (KUHPerdata).
Ketiga sistem hukum tersebut mempunyai dasar berlakunya sebagai berikut:

1. Sistem hukum perdata barat (Eropa), yang tertuang dalam bugerlijk wetboek (KUHPerdata) yang berdasarkan Pasal 131 I.S. Jo. Staatblad 1971 Nomor 12 tentang Penundukan Diri terhadap Hukum Eropa, maka bugerlijk wetboek berlaku bagi:
a. Orang-orang Eropa dan mereka yang dipersamakan dengan orang Eropa;
b. Orang Timur Asing;
c. Orang Timur asing lainnya dan orang Indonesia yang menundukkan diri pada hukum Eropa.

2. Sistem hukum kewarisan adat yang beraneka ragam pula sistemnya, dipengaruhi oleh bentuk etnik di berbagai lingkungan adat, misalnya sistem matrilineal di Minangkabau, patrilineal di Batak, bilateral di Jawa dan alterneren unilateral (sistem unilateral yang beralih) seperti di Rejang Lebong atau Lampung Papa-Don, yang diberlakukan kepada orang Indonesia yang masih erat hubungannya dengan masyarakat hukum adat yang bersangkutan. 
3. Sistem hukum kewarisan Islam, yang juga terdiri dari pluralisme ajaran, seperti ajaran ahl-Sunnah wal jama'ah, ajaran Syiah, dan ajaran Hazairin. Yang paling dominan berpengaruh di Indonesia adalah Mazhab Syafi'i sebagai ajaran ahl-Sunnah wal jama'ah (Ramulyo, 1992: 1-2).

Praktik hibah terjadi di masyarakat yang kemudian menjadi sengketa di pengadilan, pada umumnya hibah dilakukan bagi penghibah yang tidak mempunyai anak kandung atau bagi pasangan suami istri yang tidak mempunyai anak kandung, baik secara bersama-sama maupun secara sendiri-sendiri setelah pasangannya meninggal dunia, lalu menghibahkan seluruh hartanya kepada orang yang lebih dekat semasa hidupnya tanpa mempertimbangkan hak waris orang lain yang mempunyai hubungan waris karena nasab.

Putusan Nomor 454/PDT.G/2005/PA.LMG diawali ketika para penggugat mengajukan perkara pembatalan hibah karena objek sengketa yang dihibahkan oleh seorang janda pewaris merupakan boedel warisan dari almarhum suami penghibah, yang tidak lain adalah saudara kandung ayah dari para penggugat, sehingga menurut sistem kewarisan Islam, para penggugat berhak untuk mewarisi objek sengketa. Tindakan hukum yang dilakukan oleh janda pewaris berupa hibah adalah tidak sah karena objek sengketa bukan milik penghibah, namun milik para penggugat berdasarkan pewarisan.

Para penggugat maupun para tergugat semuanya beragama Islam, sehingga pengajuan pembatalan hibah ke pengadilan agama telah berdasar hukum (Pasal 2 Undang-Undang Nomor 7 Tahun 1989 tentang Peradilan Agama sebagaimana telah diubah dengan Undang-
Undang Nomor 3 Tahun 2006 dan perubahan kedua Undang-Undang Nomor 50 Tahun 2009) yang selengkapnya sebagai berikut: "Peradilan Agama merupakan salah satu pelaksanan kekuasaan kehakiman bagi rakyat pencari keadilan yang beragama Islam mengenai perkara perdata tertentu yang diatur dalam Undang-Undang ini" (Dirjen Badilag, 2015: 236). Selain itu, sengketa hibah merupakan salah satu kewenangan absolut pengadilan agama berdasarkan Pasal 49 ayat (1).

Gugatan pembatalan maupun pengesahan hibah dan wasiat diajukan kepada pengadilan agama/mahkamah syar'iyah dalam wilayah hukum di mana pihak tergugat atau salah satu bertempat tinggal (untuk luar Jawa dan Madura), dankepada pengadilan agama/mahkamahsya'iyah dalam wilayah hukum di mana objek sengketa benda tetap berada atau di tempat tergugat, bila objek sengketa berupa benda bergerak (untuk luar Jawa dan Madura) (Dirjen Badilag, 2014: 167). Dalam hal ini, baik para penggugat, tergugat maupun objek sengketa semuanya dalam wilayah Pengadilan Agama Lamongan.

Perkara pembatalan hibah ini diajukan oleh LH (penggugat I), RSA (penggugat II), dan RAS (penggugat III) melawan RAA (tergugat I), HIM (tergugat II), S (tergugat III), RS (tergugat IV), dan TW (tergugat V). Setelah melewati proses beperkara sekitar enam bulan, akhirnya majelis hakim memutuskan perkara tersebut dengan mengabulkan gugatan para penggugat. Hal itu berarti akta pengikatan perjanjian hibah oleh RAA (tergugat I) kepada tergugat II, III, dan IV dinyatakan tidak berkekuatan hukum karena objek sengketa merupakan bagian warisan para penggugat dari almarhum RM. Berdasarkan kesepakatan keluarga, sementara tergugat I (istri pewaris) mendapat dua tanah tegalan. 
Tergugat II dan III mengajukan banding dengan Putusan Nomor 280/PDT.G/2005/PTA. SBY, namun majelis hakim menguatkan Putusan Nomor 454/PDT.G/2005/PA.LMG. Karena tidak puas, tergugat II dan III mengajukan kasasi dengan Putusan Nomor 222 K/AG/2006, namun Mahkamah Agung menolak permohonan kasasi pemohon kasasi, sehingga tergugat II dan III kembali mengajukan peninjauan kembali dengan Putusan Nomor 39 PK/AG/2008, namun lagilagi majelis hakim peninjauan kembali menolak permohonan pemohon.

Tergugat II (HIM) dan III (S) selain mengajukan banding, kasasi, dan peninjauan kembali ternyata juga mengajukan gugatan kembali dengan Putusan Nomor 25/PDT.G/2006/ PN.LMG. HIM sebagai penggugat I (pada Putusan Nomor 454/PDT.G/2005/PA.LMG sebagai tergugat II) dan $\mathrm{S}$ sebagai penggugat II (pada Putusan Nomor 454/PDT.G/2005/ PA.LMG sebagai tergugat III) melawan LH sebagai tergugat I (pada Putusan Nomor 454/ PDT.G/2005/PA.LMG sebagai penggugat I) dan RS sebagai tergugat II (pada Putusan Nomor 454/ PDT.G/2005/PA.LMG sebagai tergugat IV).

Setelah melewati proses beperkara sekitar enam bulan, akhirnya majelis hakim memutuskan perkara tersebut dengan menyatakan gugatan para penggugat tidak dapat diterima dengan pertimbangan, gugatan penggugat prematur, karena untuk menyimpulkan perbuatan para tergugat dalam akad perdamaian merupakan perbuatan melawan hukum. Terlebih dahulu harus dibuktikan apakah para penggugat adalah pemilik sah atas tanah-tanah yang dijadikan objek sengketa dalam akad perdamaian tersebut yang didalilkan oleh para penggugat telah dihibahkan oleh RAA kepada para penggugat sesuai dengan akta pengikatan hibah di hadapan notaris. Padahal berdasarkan Putusan Nomor 454/PDT.G/2005/ PA.LMG jo. Putusan Nomor 280/PDT.G/2005/ PTA.SBY yang menyatakan akta pengikatan hibah Nomor 1 dan 4 tanggal 8 April 2002 belum berkekuatan hukum tetap karena masih dalam pemeriksaan kasasi.

HIM mengajukan banding karena tidak puas dengan Putusan Nomor 25/PDT.G/2006/ PN.LMG. Putusan Nomor 163/PDT.G/2008/ PT.SBY membatalkan Putusan Nomor 25/ PDT.G/2006/PN.LMG dan mengabulkan gugatan para penggugat sebagian yakni dua objek sengketa dinyatakan sebagai hak para penggugat atas dasar hibah dari janda pewaris dengan dasar kepemilikan berdasarkan pewarisan. Menurut sistem hukum bugerlijk wetboek, janda pewaris merupakan ahli waris golongan pertama yang menutup ahli waris lain karena pewaris tidak memiliki keturunan.

LH (tergugat I) dalam perkara tersebut mengajukan kasasi dengan Putusan Nomor 450 K/PDT/2009, namun permohonan kasasi tersebut ditolak. Demikian juga dengan permohonan peninjauan kembali Putusan Nomor 519 PK/ PDT./2013. Namun demikian, pada saat perkara tersebut dalam proses kasasi, para tergugat mengajukan gugatan dalam objek dan subjek yang sama ke pengadilan negeri, yang menyatakan perkara tersebut dinyatakan tidak dapat diterima (NO), akan tetapi pengadilan tinggi membatalkan putusan pengadilan negeri dan mengabulkan gugatan para penggugat.

Penyelesaian sengketa hibah di dua lembaga peradilan yang berbeda menghasilkan dua putusan lembaga peradilan yang berbeda pula. Pada tingkat banding, pengadilan tinggi mengabulkan gugatan para penggugat sebagian dengan menerapkan sistem hukum perdata barat 
dalam menetapkan hak kepemilikan penghibah terhadap objek sengketa, yakni seorang janda/ duda merupakan golongan ahli waris pertama mendapat warisan dari pewaris sebagai penghalang bagi ahli waris golongan berikutnya. Sementara pengadilan agama menerapkan sistem hukum kewarisan Islam dalam menetapkan hak milik penghibah terhadap objek sengketa, dan di samping itu tidak ada amar yang bersifat condemnatoir yang menjadi salah satu syarat suatu putusan dapat dieksekusi. Dua putusan yang saling berlawanan dari dua lembaga peradilan yang berbeda mengakibatkan para pencari keadilan tidak mendapatkan kepastian lembaga peradilan mana yang berhak mengeksekusi dua putusan yang berbeda tersebut.

\section{B. Rumusan Masalah}

Berdasarkan latar belakang di atas, rumasan masalah yang diangkat dalam kajian ini adalah:

1. Apakah pertimbangan hukum pengadilan negeri dalam menerima dan mengadili perkara ini dapat dibenarkan menurut kompetensi absolut yang dimilikinya?

2. Apakah asas ne bis in idem dapat diterapkan dalam hal pengadilan negeri mengadili perkara yang sudah diputus oleh pengadilan agama?

\section{Tujuan dan Kegunaan}

Tujuan tulisan ini adalah untuk mengetahui dan menganalisis apakah pertimbangan hukum pengadilan negeri dalam menerima dan mengadili perkara ini dapat dibenarkan menurut kompetensi absolut yang dimilikinya; dan untuk mengetahui apakah asas ne bis in idem dapat diterapkan dalam hal pengadilan negeri mengadili perkara yang sudah diputus oleh pengadilan agama.

Kegunaan atau manfaat yang diperoleh adalah untuk mendapatkan solusi agar para pencari keadilan dapat memperoleh hak-haknya pasca putusan berkekuatan hukum tetap terhadap dua putusan lembaga peradilan (peradilan umum dan peradilan agama) yang saling berlawanan dan masing-masing putusan sampai tingkat peninjauan kembali serta menemukan konsep upaya hukum yang harus ditempuh oleh para pencari keadilan agar putusan yang tidak mengandung amar yang bersifat condemnatoir dapat dieksekusi.

\section{Tinjauan Pustaka}

\section{Kewenangan Pengadilan Agama} Mengadili Sengketa Hibah

Peradilan agama merupakan salah satu pelaku kekuasaan kehakiman bagi masyarakat pencari keadilan yang beragama Islam yang diatur dalam Undang-Undang Nomor 7 Tahun 1989 tentang Peradilan Agama sebagaimana telah diubah dengan Undang-Undang Nomor 3 Tahun 2006 dan perubahan kedua Undang-Undang Nomor 50 Tahun 2009 (Wirhanuddin, 2014: 103). Kekuasaan kehakiman di lingkungan peradilan agama dilaksanakan oleh pengadilan agama dan pengadilan tinggi agama yang berpuncak pada Mahkamah Agung, sesuai prinsip-prinsip yang ditentukan oleh Undang-Undang Nomor 14 Tahun 1970 (Dirjen Badilag, 2014: 264).

Kewenangan absolut pengadilan agama yang diatur secara eksplisit pada Pasal 49 UndangUndang Nomor 7 Tahun 1989 memberikan kewenangan untuk memeriksa, memutus, dan menyelesaikan perkara-perkara pada tingkat pertama antara orang-orang yang beragama Islam di bidang: 
a. Perkawinan;

b. Kewarisan, wasiat, dan hibah yang dilakukan berdasarkan hukum Islam;

c. Wakaf dan sedekah (Alim, 2013: 40).

Dengan demikian, sengketa hibah merupakan salah satu kewenangan absolut pengadilan agama di samping sengketa waris, wasiat, hibah, dan lain-lain. Khusus untuk kewenangan pengadilan agama dalam memeriksa, mengadili, dan memutus perkara-perkara waris berdasarkan Undang-Undang Nomor 7 Tahun 1989, masih dibatasi dengan adanya hak opsi.

Hak opsi adalah hak memilih hukum warisan apa yang akan dipergunakan dalam menyelesaikan pembagian warisan. Jadi hak opsi adalah pilihan hukum bagi pada pihak yang bersengketa khusus dalam perkara warisan untuk menempuh penyelesaian melalui jalur hukum perdata (burgerlijk wetboek) atau hukum adat atau hukum Islam. Hal tersebut ditegaskan dalam Penjelasan Umum angka 2 alinea ke-5 yang menyatakan: "Para pihak sebelum beperkara dapat mempertimbangkan untuk memilih hukum apa yang dipergunakan dalam pembagian warisan” (Dirjen Badilag, 2014: 264).

Mengenai hak opsi ini, Mahkamah Agung memberikan petunjuk bagi hakim-hakim dalam menyelesaikan perkara warisan dengan mengeluarkan SEMA Nomor 2 Tahun 1990 tentang Petunjuk Pelaksanaan Undang-Undang Nomor 7 Tahun 1989 yang menyatakan bahwa ketentuan pilihan hukum warisan merupakan permasalahan yang terletak di luar badan peradilan dan berlaku bagi golongan rakyat yang hukum kewarisannya tunduk pada hukum adat dan/atau hukum perdata barat (burgerlijk wetboek) dan/ atau hukum Islam. Para pihak boleh memilih hukum adat atau hukum perdata barat (burgerlijk wetboek) yang menjadi wewenang pengadilan negeri atau memilih hukum Islam yang menjadi wewenang pengadilan agama (Dirjen Badilag, 2014: 1192).

Pilihan hukum itu berlaku sebelum perkara diajukan ke pengadilan. Apabila suatu perkara warisan dimasukkan ke pengadilan agama maka pihak lawan telah gugur haknya untuk menentukan pilihan hukum dalam menyelesaikan perkara warisan. Apabila dalam perkara warisan diajukan ke pengadilan agama dan pengadilan negeri secara bersamaan oleh para pihak yang bersengketa, maka hal ini telah terjadi sengketa kewenangan mengadili antara pengadilan pada badan peradilan yang satu dengan pengadilan pada badan peradilan yang lain, sehingga harus diselesaikan dahulu melalui Mahkamah Agung sebagai pengadilan tingkat terakhir. Perkara ditunda sampai ada putusan Mahkamah Agung, pengadilan mana yang berhak mengadili perkara tersebut.

Hak opsi bagi para pihak yang bersengketa dalam bidang kewarisan dinyatakan dihapus dengan diundangkannya Undang-Undang Nomor 3 Tahun 2006 tentang Perubahan Pertama Undang-Undang Nomor 7 Tahun 1989 tentang Peradilan Agama (Lembaran Negara Republik Indonesia Tahun 2009 Nomor 159, tambahan Lembaran Negara Republlik Indonesia Nomor 5078), terdapat tambahan kewenangan peradilan agama yang dituangkan pada Pasal 49, dan tetap disebut secara tegas hibah merupakan kewenangan mutlak pengadilan agama. Setelah diberlakukan Undang-Undang Nomor 3 Tahun 2006 tentang Perubahan Pertama UndangUndang Nomor 7 Tahun 1989 tentang Peradilan Agama, kewenangan pengadilan agama ditambah dengan perkara infak, zakat, dan ekonomi syariah (Kamil, 2016: 246), 
Adanya perubahan atas Undang-Undang Nomor 7 Tahun 1989 tentang Peradilan Agama menjadi Undang-Undang Nomor 3 Tahun 2006, kalimat yang terdapat dalam Penjelasan Umum Undang-Undang Nomor 7 Tahun 1989 tentang Peradilan Agama yang menyatakan: "Para pihak sebelum beperkara dapat mempertimbangkan untuk memilih hukum apa yang dipergunakan dalam pembagian warisan," dinyatakan dihapus, sehingga tidak ada lagi pilihan bagi umat Islam untuk memilih sistem hukum lain kecuali hukum Islam dalam hal pembagian harta warisan.

\section{Asas Ne Bis In Idem}

Ne bis in idem merupakan asas hukum yang berlaku secara umum, baik di bidang hukum perdata maupun pidana. Dalam hukum perdata, asas ini berarti perkara dengan objek yang sama, subjek (pihak) yang sama, dan pokok sengketa yang sama, telah diputus oleh pengadilan dan telah berkekuatan hukum tetap dengan putusan yang bersifat positif (mengabulkan atau menolak), tidak boleh diperiksa kembali untuk kedua kalinya.

Pengertian tentang asas ne bis in idem diatur pada Pasal 1917 KUHPerdata disebutkan bahwa: "Kekuatan suatu putusan hakim yang telah memperoleh kekuatan hukum mutlak tidaklah lebih luas dari pada sekadar mengenai soal putusannya. Untuk dapat memajukan kekuatan itu perlulah bahwa soal yang dituntut adalah sama, bahwa tuntutan didasarkan alasan yang sama dalam hubungan yang sama pula." Hal itu berarti bahwa suatu perkara yang telah diputus oleh hakim terdahulu dan telah memperoleh kekuatan hukum tetap, tidak dapat digugat kembali dengan subjek dan objek yang sama (Ibrahim, 2014).
Dengan demikian, putusan hakim yang telah mempunyai kekuatan hukum tetap, harus dilaksanakan, tidak bisa untuk tidak dilaksanakan. Tidak boleh diajukan gugatan baru yang mempersoalkan substansi yang sama sebagaimana telah diputus dalam putusan hakim yang telah berkekuatan hukum tetap. Gugatan yang mempersoalkan persoalan yang sama dengan substansi yang telah diputus dan berkekuatan hukum tetap itulah yang dinamakan ne bis in idem (Islamey et al., 2012). Itulah sebabnya, secara hukum suatu gugatan dinyatakan ne bis in idem apabila memenuhi kriteria sebagai berikut:

a. Perkara yang digugat adalah perkara yang telah diajukan sebelumnya.

b. Telah ada putusan yang telah mempunyai kekuatan hukum tetap yang bersifat positif (menolak atau mengabulkan).

c. Perkara yang digugat adalah perkara objek dan subjek yang sama serta pokok sengketa yang sama.

Penerapasan asas ne bis in idem ditegaskan dalam SEMA Nomor 3 Tahun 2002 tentang Penanganan Perkara yang Berkaitan dengan Asas $\mathrm{Ne}$ Bis In Idem. SEMA tersebut mengimbau para ketua pengadilan untuk dapat melaksanakan asas ne bis in idem dengan baik dan sangat berhatihati demi kepastian bagi pencari keadilan dengan menghindari adanya putusan yang berbeda pada lingkungan peradilan umum, peradilan agama, dan peradilan tata usaha negara. Dalam SEMA tersebut diatur tentang tiga hal, yaitu:

a. $\quad$ Proses di pengadilan yang sama;

b. Proses di pengadilan yang berbeda lingkungan;

c. Proses pengiriman ke Mahkamah Agung. 


\section{METODE}

Pengumpulan data atau bahan hukum dalam penelitian pustaka adalah teknik dokumenter, yaitu dikumpulkan dari telaah arsip atau studi pustaka pada pengadilan agama. Penulis membuat catatan penting tentang hambatan yuridis eksekusi akibat ada dua putusan pada dua lembaga peradilan yang berbeda dan masingmasing telah berkekuatan hukum tetap dengan fokus pada Putusan Nomor 454/PDT.G/2005/ PA.LMG dan Nomor 163/PDT.G/2008/PT.SBY. Menelaah dan menyeleksi penalaran hukum majelis hakim dengan fokus permasalahan, menyusun aturan relevan yang menjadi perangkat hukum alat kritiknya dan memberi solusi atas permasalan penetapan kewenangan eksekusi atas dua putusan lembaga peradilan yang masingmasing telah berkekuatan hukum tetap.

Adapun metode analisis data yang digunakan adalah bersifat kualitatif, yakni menjelaskan data-data yang ada dengan katakata atau pernyataan, bukan angka-angka. Dalam tulisan ini penulis akan mengidentifikasi fakta hukum dan fakta peristiwa terkait pertimbangan majelis hakim dalam Putusan Nomor 454/PDT.G/2005/PA.LMG dan Nomor 163/PDT.G/2008/PT.SBY. Penulis juga akan mengidentifikasi fakta hukum dan fakta peristiwa terkait pertimbangan majelis hakim tingkat pertama dan banding sebagai subbahasan. Konstruksi kritik tersebut diperoleh dari hasil analisis data atas pertimbangan hakim tingkat pertama dan banding serta garis besar pemikiran dari hasil bacaan fikih dan aturan undang-undang. Subbahasan selanjutnya menawarkan solusi atas kritik yang dimunculkan sebagai pengembangan dari analisis data pemikiran ahli agar dalam mengadili kasus serupa, tidak terkendala dalam eksekusi.

\section{HASIL DAN PEMBAHASAN}

Pertimbangan hukum pengadilan agama dalam mengabulkan gugatan pembatalan hibah para penggugat adalah bahwa tergugat I (RAA) telah menghibahkan kepada tergugat II, III, dan IV suatuhartayang bukanmiliknyakarena didalamnya terkandung hak orang lain selaku ahli waris karena hubungan nasab yang berhak mendapatkan bagian dari harta tersebut serta berdasarkan kesepakatan keluarga. Objek sengketa disepakati merupakan bagian para penggugat, sementara janda almarhum (RAA) disepakati mendapat dua tanah tegalan.

Penalaran hukum yang juga dapat berarti proses penggunaan alasan-alasan hukum (legal reasons) dalam menetapkan pendirian hukum yang dirumuskan dalam putusan hakim (Mappiasse, 2015,87 ) oleh majelis hakim pengadilan agama yang telah mengabulkan perkara tersebut, dapat disimpulkan sebagai berikut:

a. Objek sengketa merupakan harta peninggalan seorang pewaris, dan tergugat I selaku janda pewaris bukan satu-satu ahli waris karena masih ada ahli waris lain yang merupakan ahli waris karena hubungan nasab/darah serta berhak atas harta peninggalan pewaris.

b. Bahwa harta yang dihibahkan adalah harta milik pribadi seseorang, oleh karenanya hibah tergugat I kepada tergugat II, III, dan IV bertentangan dengan hukum syara' yang berlaku.

c. Telah ada kesepakatan para ahli waris bahwa objek sengketa merupakan bagian para penggugat sebagai ahli waris karena hubungan nasab/darah dan tergugat I selaku janda pewaris mendapat dua bidang tanah tegalan lainnya. 
Pertimbangan hukum pengadilan tinggi agama dalam menguatkan putusan pengadilan agama adalah tepat dan benar dalam pertimbangannya.

Mahkamah Agung dalam pemeriksaan tingkat kasasi akan membatalkan putusan dan penetapan pengadilan tingkat lebih rendah (yang belum mempunyai kekuatan hukum tetap), karena tidak berwenang atau melampaui wewenang; salah menerapkan hukum atau melanggar hukum yang berlaku; dan lalai memenuhi syarat yang diwajibkan oleh peraturan perundang-undangan yang mengancam kelalaian itu dengan batalnya putusan yang bersangkutan (Manan, 2015: 22).

Kaitannya dengan hal tersebut, majelis hakim tingkat kasasi menolak permohonanan kasasi para pemohon kasasi dengan pertimbangan judex facti tidak salah menerapkan hukum. Mengenai penilaian hasil pembuktian yang bersifat penghargaan terhadap suatu kenyataan, hal mana tidak dapat dipertimbangkan dalam permohonan kasasi karena permohonan kasasi berkenaan dengan tidak dilaksanakan atau ada kelalaian dalam penerapan hukum atau peraturan perundang-undangan yang berlaku. Demikian juga dengan peninjauan kembali. Majelis hakim yang memeriksa perkara tersebut mempertimbangkan bahwa judex facti dan judex jurist tidak salah dalam menerapkan hukum sebagai alasan peninjauan kembali, karenanya permohonan peninjauan kembali para pemohon dinyatakan ditolak.

Pengadilan negeri menyatakan gugatan para penggugat tidak dapat diterima dengan pertimbangan bahwa gugatan penggugat prematur, karena untuk menyimpulkan perbuatan para tergugat dalam akad perdamaian merupakan perbuatan melawan hokum. Terlebih dahulu harus dibuktikan apakah para penggugat adalah pemilik sah atas tanah-tanah yang dijadikan objek sengketa dalam akad perdamaian yang didalilkan oleh para penggugat telah dihibahkan oleh RAA kepada para penggugat sesuai dengan akta pengikatan hibah di hadapan notaris. Padahal berdasarkan Putusan Nomor 454/PDT.G/2005/PA.LMG jo. Putusan Nomor 280/PDT.G/2005/PTA.SBY yang menyatakan akta pengikatan hibah Nomor 1 dan 4 tanggal 8 April 2002 belum berkekuatan hukum tetap dan dalam pemeriksaan kasasi.

Pengadilan tinggi tidak sependapat dengan putusan negeri. Itulah sebabnya, pengadilan tinggi membatalkan putusan negeri dengan pertimbangan bahwa putusan pengadilan agama dan pengadilan tinggi agama belum mempunyai kekuatan hukum tetap karena dalam proses kasasi adalah menyangkut keabsahan akta perjanjian pengikatan hibah, sedangkan perkara yang diperiksa adalah menyangkut perbuatan melawan hukum yang dilakukan oleh para tergugat pada tanggal 8 November 2004. Walaupun ada hubungan antara perbuatan melawan hukum dalam perkara ini dengan akta perjanjian pengikatan hibah, tetapi yang menjadi pokok sengketa dalam perkara tersebut tidak tergantung seutuhnya pada akta perjanjian pengikatan hibah dan dapat saja diperiksa serta diputus sendiri secara terpisah, karena perbuatan melawan hukum yang dituntut adalah perbuatan yang dilakukan sebelum adanya sengketa keabsahan akta perjanjian pengikatan hibah. Oleh karenanya gugatan para penggugat tidak bersifat prematur.

Pertimbangan hukum selanjutnya adalah bahwa tanah objek sengketa merupakan harta bersama RM dengan RAA karena telah diberikan menjadi hak milik RM oleh pemerintah cq. Menteri Agraria dan keduanya dalam ikatan perkawinan yang sah. Bahwa RM telah meninggal dunia tahun 1992, sehingga 
berdasarkan ketentuan pewarisan menurut Pasal 852 huruf a KUHPerdata (burgerlijk wetboek), RAA sebagai istri adalah ahli waris 1 , sedangkan L (tergugat) adalah saudara kandung yang dalam hal ini cucu dari saudara laki-laki RM adalah ahli waris golongan II (Pasal 856 burgerlijk wetboek). Asas hukum waris, golongan yang dekat menutup warisan bagi golongan yang berada di bawahnya, sehingga RAA satu-satunya ahli waris RM dan mempunyai kewenangan untuk melakukan perbuatan hukum, termasuk menghibahkan.

Permohonan kasasi yang diajukan oleh tergugat 1 (L) ditolak oleh Mahkamah Agung dengan Putusan Nomor 450 K/PDT/2009 dengan dasar pertimbangan pengadilan tinggi yaitu tidak salah menerapkan hukum karena objek sengketa awalnya tanah negara yang diberikan kepada RM oleh pemerintah cq. Menteri Agraria tanggal 7 September 1964 pada saat suami istri secara sah dengan RAA, sehingga menjadi harta bersama. Pada tanggal 13 April 1992 pewaris meninggal dunia, sehingga harta warisan satu-satunya untuk RAA. Pertimbangan selanjutnya tanah objek sengketa dihibahkan kepada penggugat dan tergugat II, karenanya hibah tersebut adalah sah dan tanah objek sengketa menjadi milik penggugat dan tergugat II.

Peninjauan kembali yang diajukan oleh tergugat 1 dinyatakan ditolak dengan Putusan Nomor 519 PK/PDT/2013, dengan pertimbangan tidak ditemukan adanya kekhilafan dan kekeliruan yang nyata baik oleh judex facti maupun judex jurist, karena perkara ini telah dipertimbangkan dengan benar oleh pengadilan tinggi dan judex jurist.

Peninjauan kembali hanya merupakan perbedaan pendapat antara pemohon dengan judex facti maupun judex jurist yang bukan merupakan alasan peninjauan kembali. Amar putusan dari semua pengadilan di atas dapat dilihat dalam tabel 1 dan 2 berikut ini:

Tabel 1. Putusan Nomor 454/PDT.G/2005/PA.LMG; Nomor 280/PDT.G/2005/PTA.SBY; Nomor 222 K AG/2006; dan Nomor 39 PK/AG/2008

\begin{tabular}{|c|c|c|}
\hline No. & Putusan & Amar Putusan \\
\hline 1. & $\begin{array}{l}\text { Putusan Nomor 454/PDT.G/2005/ } \\
\text { PA.LMG tanggal } 13 \text { September } 2005 .\end{array}$ & $\begin{array}{l}\text { Mengabulkan gugatan para penggugat dengan menyatakan } \\
\text { tergugat I (RAA) bukan pewaris tunggal dari RM, sehingga } \\
\text { tanah sawah dan tanah pekarangan yang dihibahkan oleh } \\
\text { tergugat I (RAA) kepada tergugat II (HIM), tergugat III (S), } \\
\text { dan tergugat IV (RS) adalah harta peninggalan RM yang di } \\
\text { dalamnya terkandung hak para ahli warisnya dan karenanya } \\
\text { Akta Perjanjian Pengikatan Hibah Nomor } 1 \text { dan } 4 \text { tanggal } 8 \\
\text { April } 2002 \text { yang dibuat di hadapan notaris di lapangan tidak } \\
\text { berkekuatan hukum. }\end{array}$ \\
\hline 2. & $\begin{array}{l}\text { Putusan Nomor 280/PDT.G/2005/ } \\
\text { PTA.SBY tanggal } 27 \text { Desember } 2005 .\end{array}$ & $\begin{array}{l}\text { Menguatkan putusan pengadilan agama tanggal } 13 \text { September } \\
2005 \text {. }\end{array}$ \\
\hline 3. & $\begin{array}{l}\text { Putusan Nomor } 222 \mathrm{~K} / \mathrm{AG} / 2006 \\
\text { tanggal } 27 \text { September } 2006 .\end{array}$ & Menolak permohonan kasasi dari para pemohon kasasi. \\
\hline 4. & $\begin{array}{l}\text { Putusan Nomor } 39 \text { PK/AG/2008 } \\
\text { tanggal } 21 \text { November } 2008 \text {. }\end{array}$ & $\begin{array}{l}\text { Menguatkan putusan pengadilan agama tanggal } 13 \text { September } \\
2005 \text {. }\end{array}$ \\
\hline
\end{tabular}


Tabel 2. Putusan Nomor 25/PDT.G/2006/PN.LMG; Nomor 163/PDT.G/2008/PT.SBY; Nomor 450 K/PDT/2009; dan Nomor 519 PK/PDT.G/2013

\begin{tabular}{cll} 
No. & \multicolumn{1}{c}{ Putusan } & \multicolumn{1}{c}{ Amar Putusan } \\
\hline 1. & $\begin{array}{l}\text { Putusan Nomor 25/PDT.G/2006/ } \\
\text { PN.LMG tanggal 4 April 2007. }\end{array}$ & Menyatakan gugatan para penggugat tidak dapat diterima. \\
\hline 2. & $\begin{array}{l}\text { Putusan Nomor 163/PDT.G/2008/ } \\
\text { PT.SBY tanggal 13 Agustus 2008. }\end{array}$ & $\begin{array}{l}\text { Membatalkan putusan pengadilan negeri dan mengabulkan } \\
\text { gugatan penggugat sebagian. }\end{array}$ \\
& & $\begin{array}{l}\text { Menetapkan keabsahan akta perjanjian pengikatan hibah } \\
\text { yang sama objeknya dalam Putusan Nomor 454/PDT.G/2005/ }\end{array}$ \\
& & $\begin{array}{l}\text { PA.LMG tanggal 13 September 2005 yang menyatakan Akta } \\
\text { Pengikatan Hibah Nomor 1 dan 4 tanggal 8 April 2002 tidak } \\
\text { mempunyai kekuatan hukum. }\end{array}$ \\
& & $\begin{array}{l}\text { Menetapkah objek sengketa sebagai hak para penggugat serta } \\
\text { menyatakan para tergugat melakukan perbuatan melawan } \\
\text { hukum dan membatalkan akta perdamaian pembagian harta } \\
\text { waris pewaris. }\end{array}$ \\
\hline 3. & $\begin{array}{l}\text { Putusan Nomor 450 K/PDT/2009 permohonan kasasi para pemohon kasasi. } \\
\text { tanggal 20 April 2011. }\end{array}$ & $\begin{array}{l}\text { Menolak permohonan peninjauan kembali para pemohon } \\
\text { Putusan Nomor 519 PK/PDT.G/2013 } \\
\text { tanggal 11 Desember 2014. }\end{array}$ \\
\hline
\end{tabular}

\section{A. Dari Segi Kewenangan Pengadilan}

Pertimbangan hukum majelis hakim pengadilan negeri memeriksa dan mengadili Putusan Nomor 25/PDT/2006/PN.LMG sudah tepat karena menjadi pokok sengketa yang dipertimbangkan dalam perkara tersebut perbuatan melawan hukum yang merupakan kewenangan absolutnya. Namun demikian, majelis hakim dalam putusan menyatakan gugatan para penggugat tidak dapat diterima dengan pertimbangan bahwa gugatan penggugat prematur, karena untuk menyimpulkan perbuatan para tergugat dalam akad perdamaian merupakan perbuatan melawan hukum, terlebih dahulu harus dibuktikan apakah para penggugat adalah pemilik sah atas tanah-tanah yang dijadikan objek sengketa dalam akad perdamaian yang didalilkan oleh para penggugat telah dihibahkan oleh RAA kepada para penggugat sesuai dengan akta pengikatan hibah di hadapan notaris, padahal berdasarkan Putusan Nomor 454/PDT.G/2005/PA.LMG jo.
Putusan Nomor 280/PDT.G/2005/PTA.SBY yang menyatakan Akta Pengikatan Hibah Nomor 1 dan 4 tanggal 8 April 2002, belum berkekuatan hukum tetap dan dalam pemeriksaan kasasi.

Pertimbangan hukum pengadilan negeri tersebut di atas, berbeda dengan pertimbangan hukum majelis hakim pengadilan tinggi pada Putusan Nomor 163/PDT/2007/PT.SBY yang membatalkan putusan pengadilan negeri. Pada satu sisi, majelis hakim pengadilan tinggi mempertimbangkan pokok sengketa perkara tersebut adalah perbuatan melawan hukum dan menjadi kewenangan absolutnya. Namun pada sisi lain, yang pertama harus dipertimbangkan dalam perkara tersebut adalah hak kepemilikan para penggugat berdasarkan hibah akibat pewarisan antara orang-orang yang beragama Islam, sehingga pokok sengketanya adalah keabsahan hibah yang terkait dengan pewarisan orang-orang Islam, sementara perbuatan melawan hukum adalah pokok sengketa yang assesoir. Oleh karena pokok sengketa perkara tersebut 
adalah hibah akibat pewarisan, maka tidak lagi menjadi kewenangan absolut pengadilan negeri sejak diundangkan Undang-Undang Nomor 7 Tahun 1989 tentang Peradilan Agama.

Pertimbangan hukum majelis hakim tentang kewenangan absolut dalam memeriksa dan mengadili sengketa hibah Putusan Nomor 454/PDT.G/2005/PA.LMG sudah tepat karena sengketa hibah merupakan kewenangan absolut pengadilan agama. Hal itu diatur secara eksplisit pada Pasal 49 Undang-Undang Nomor 7 Tahun 1989 tentang Peradilan Agama. Adapun sengketa waris sebagai dasar kepemilikan objek sengketa, berdasarkan Undang-Undang Nomor 7 Tahun 1989 tentang Peradilan Agama, masih dibatasi dengan adanya hak opsi, yakni hak memilih hukum warisan perdata (burgerlijk wetboek) atau hukum adat atau hukum Islam yang akan dipergunakan dalam menyelesaikan pembagian warisan.

Hak opsi atau pilihan hukum itu berlaku sebelum perkara diajukan ke pengadilan, sehingga apabila suatu perkara warisan telah didaftarkan ke pengadilan agama, maka pihak lawan telah gugur haknya untuk menentukan pilihan hukum dalam menyelesaikan perkara warisan. Apabila dalam perkara warisan diajukan ke pengadilan agama dan pengadilan negeri secara bersamaan oleh para pihak yang bersengketa, maka hal tersebut berarti telah terjadi sengketa kewenangan mengadili antara pengadilan pada badan peradilan yang satu dengan pengadilan pada badan peradilan yang lain sehingga harus diselesaikan dahulu melalui Mahkamah Agung sebagai pengadilan tingkat terakhir.

Prosesnya adalah perkara ditunda sampai ada putusan Mahkamah Agung yang menetapkan pengadilan mana yang berhak mengadili perkara tersebut.
Hak opsi bagi para pihak yang bersengketa dalam bidang kewarisan dinyatakan dihapus dengan diundangkannya Undang-Undang Nomor 3 Tahun 2006 tentang Perubahan Pertama Undang-Undang Nomor 7 Tahun 1989 tentang Peradilan Agama, sehingga tidak ada pilihan bagi pencari keadilan yanag beragama Islam, kecuali mengajukan perkaranya ke pengadilan agama setelah tahun 2006.

Terjadi dua putusan yang berbeda pada dua lembaga peradilan dan menjadi sengketa titik singgung kewenangan dengan putusan pengadilan tinggi yang membatalkan putusan pengadilan negeri dengan pertimbangan bahwa putusan pengadilan agama dan pengadilan tinggi agama belum mempunyai kekuatan hukum tetap karena masuh dalam proses kasasi yaitu menyangkut keabsahan akta perjanjian pengikatan hibah, sedangkan perkara yang diperiksa adalah menyangkut perbuatan melawan hukum yang dilakukan oleh para tergugat.

Amar putusan pengadilan tinggi menetapkan keabsahan akta perjanjian pengikatan hibah yang sama objeknya dalam Putusan Nomor 454/PDT.G/2005/PA.LMG yang menyatakan Akta Pengikatan Hibah Nomor 1 dan 4 tidak mempunyai kekuatan hukum.

Pengadilan agama dalam Putusan Nomor 454/PDT.G/2005/PA.LMG menerapkan sistem hukum kewarisan Islam dalam menentukan hak kepemilikan janda pewaris, sehingga selain janda pewaris (karena tidak mempunyai anak), terdapat ahli waris lain yang juga berhak secara hukum atas harta warisan pewaris karena hubungan nasab/darah. Sementara pengadilan tinggi dalam putusannya menerapkan sistem hukum (burgerlijk wetboek) dan menetapkan istri adalah ahli waris golongan I yang menutup ahli waris golongan 
yang berada di bawahnya untuk mendapatkan harta warisan pewaris berdasarkan asas hukum kewarisan, sehingga RAA selaku istri pewaris adalah satu-satunya ahli waris pewaris.

Baik para penggugat maupun para tergugat masing-masing beragama Islam, maka sudah sepatutnya dipertimbangkan adalah sistem hukum kewarisan dan hibah yang dianut oleh para pihak beperkara. Mohammad Daud Ali mengatakan, seorang yang telah memilih Islam sebagai agamanya, tidak ada pilihan baginya selain memilih hukum kewarisan, wasiat, dan hibah Islam (Qohar et al., 2011: 9).

Menyimpangi ketentuan hukum kewarisan Islam, dalam membagi harta dengan mengambil hukum kewarisan lain, dapat diartikan sebagai pelanggaran hak dan kewajiban seorang beragama Islam (muslim), karena hak mereka sudah ditetapkan oleh Allah dalam Al Quran, dan itu sudah menjadi bagiannya dan harus diberikan kepadanya. Akan tetapi apabila mereka sudah melaksanakannya menurut ketentuan hukum kewarisan Islam, kemudian setelah orang yang berhak mewarisi menerima bagiannya sesuai haknya masing-masing, lalu melepaskan haknya dan memberikan kepada ahli waris lain yang belum mapan status ekonominya, maka yang demikian itu dapat dibenarkan menurut hukum kewarisan Islam (Qohar et al., 2011: 10).

Pertimbangan hukum majelis hakim pengadilan agama dalam menetapkan para penggugat sebagai ahli waris sudah tepat berdasarkan sistem kewarisan hukum Islam dan pertimbangan hukum tentang pembatalan hibah para penggugat sudah tepat karena tergugat I (janda pewaris) telah menghibahkan kepada tergugat II, III, dan IV suatu harta yang bukan miliknya karena di dalamnya terkandung hak para penggugat selaku ahli waris karena hubungan nasab yang berhak mendapatkan bagian dari harta warisan pewaris.

Dari segi penerapan asas ne bis in idem yang pada dasarnya untuk menghindari terjadinya perbedaan putusan, baik dalam lingkungan peradilan itu sendiri maupun antara lingkungan peradilan dalam hal ini pengadilan negeri mengadili perkara yang telah diputus oleh pengadilan agama. Sebagaimana telah diatur dalam SEMA Nomor 3 Tahun yang mengimbau para ketua pengadilan untuk dapat melaksanakan asas ne bis in idem dengan baik dan sangat berhati-hati demi kepastian bagi pencari keadilan dengan menghindari adanya putusan yang berbeda pada lingkungan peradilan umum, peradilan agama, dan peradilan tata usaha negara. Namun demikian, satu persyaratan yang tidak dapat diterapkannya asas ne bis in idem dalam kasus tersebut karena putusan pengadilan agama belum mempunyai kekuatan hukum tetap karena masih dalam proses kasasi pada saat perkara dengan objek dan subjek yang sama serta pokok sengketa yanag sama.

Amar Putusan Nomor 454/PDT.G/2005/ PA.LMG kurang sempurna dan tidak tuntas untuk memberikan kepastian hukum bagi para pencari keadilan untuk memperoleh hak-haknya pasca putusan berkekuatan hukum tetap disebabkan tidak mencantumkan penghukuman kepada pihak para tergugat untuk menyerahkan objek sengketa kepada para penggugat atau dalam putusan tersebut tidak ada amar condemnatoir. Konsekuensinya, putusan tersebut tidak dapat dieksekusi atau putusan yang tidak mempunyai titel eksekutorial.

Suatu putusan yang mempunyai titel eksekutorial adalah putusan yang bersifat atau 
mengandung amar condemnatoir, sedangkan putusan yang bersifat deklaratoir dan constitutif tidak dilaksanakan eksekusi (Nessa et al., 2016: 226). Putusan condemnatoir adalah putusan yang menghukum pihak beperkara untuk melakukan sesuatu/tidak melakukan sesuatu, memenuhi suatu prestasi atau menyerahkan sesuatu pada pihak lawan, misalnya menghukum agar pihak yang kalah menyerahkan objek sengketa kepada pihak yang menang atau menghukum kedua belah pihak untuk membagi harta warisan (Anshoruddin et al., 2016: 106).

Agar putusan yang bersifat deklaratoir dan constitutif dapat dieksekusi, upaya yang harus ditempuh adalah mengajukan gugatan perubahan atau penambahan amar condemnatoir. Jika hakim lupa atau lalai mencantumkan amar condemnatoir, maka pihak yang ingin agar putusan itu dijalankan harus mengajukan gugatan baru ke pengadilan agama yang memutuskan perkara semula, dengan dalil gugat berdasarkan putusan deklaratoir dan minta petitum agar barang-barang yang telah diputus dalam perkara terdahulu supaya dieksekusi dan kalau dapat diminta putusan uitvoerbaar bij vooraad (Manan, 2001: 226).

Gugatan perubahan amar merupakan perkara baru. Yang dimaksud dengan perkara baru adalah putusan yang berdiri sendiri dengan perkara lain atau perkara terdahulu, pengggat juga harus membayar biaya perkara secara tersendiri. Posita dalam perkara baru tersebut dikaitkan dengan perkara terdahulu supaya dapat dijalankan dan dapat dieksekusi sebagaimana mestinya. Dalam hal gugat baru dengan petitum perubahan amar putusan, tidak akan terjadi ne bis in idem karena hakim tidak memeriksa pokok perkara yang telah diputus dalam putusan sebelumnya (Manan, 2001: 226). Oleh sebab itu, agar putusan dalam perkara tersebut dapat dieksekusi, para penggugat mengajukan gugatan baru ke pengadilan agama, dengan dalil gugatan berdasarkan putusan deklaratoir dan meminta penambahan amar condemnatoir agar objek sengketa yang telah diputus dalam perkara tersebut dapat dieksekusi.

\section{KESIMPULAN}

Pokok sengketa dalam perkara yang telah dianalisis adalah keabsahan hibah yang terkait dengan pewarisan orang-orang Islam dan perbuatan melawan hukum adalah pokok sengketa yang assesoir. Maka perkara tersebut tidak lagi menjadi kewenangan absolut pengadilan negeri menurut Undang-Undang Nomor 7 Tahun 1989 tentang Peradilan Agama. Adanya perbedaan pokok sengketa yang harus dipertimbangkan lebih awal dalam perkara yang dianalisis dalam tulisan ini memunculkan konflik kewenangan absolut.

Dasar dari konflik adalah pertimbangan hukum majelis hakim pengadilan agama dalam mengabulkan gugatan pembatalan hibah para penggugat. Tergugat I (janda pewaris) telah menghibahkan kepada tergugat II, III, dan IV suatu harta yang bukan miliknya karena di dalamnya terkandung hak ahli waris karena hubungan nasab/darah. Pertimbangan hukum majelis hakim pengadilan tinggi dalam mengabulkan gugatan para penggugat dan membatalkan putusan pengadilan negeri adalah pewaris telah meninggal dunia pada tahun 1992.

Berdasarkan ketentuan pewarisan menurut KUHPerdata, istri adalah ahli waris golongan I, dan para tergugat dalam Putusan Nomor 163/ PDT.G/2008/PT.SBY adalah cucu dari saudara kandung pewaris (ahli waris golongan II). Asas hukum waris menurut KUHPerdata adalah 
golongan yang dekat menutup golongan ahli waris di bawahnya. Sehingga RAA satu-satunya ahli waris pewaris dan mempunyai kewenangan untuk melakukan perbuatan hukum, termasuk menghibahkan kepada para tergugat dalam Putusan Nomor 163/PDT.G/2008/PT.SBY.

\section{Putusan Nomor 454/PDT.G/2005/PA.LMG} sudah tepat sepanjang menyangkut kewenangan absolut pengadilan agama dan penetapan ahli waris berikut pembatalan hibah berdasarkan sistem hukum kewarisan Islam. Namun demikian, putusan tersebut kurang lengkap karena tidak ada amar putusan yang bersifat condemnatoir yang mengakibatkan tidak ada kepastian hukum bagi para pencari keadilan untuk memperoleh haknya pasca putusan berkekuatan hukum tetap.

Penerapan asas ne bis in idem yang pada dasarnya untuk menghindari terjadinya perbedaan putusan antara lingkungan peradilan sebagaimana telah diatur dalam SEMA Nomor 3 Tahun 2002. Pada kasus yang dibahas dalam tulisan ini, asas ne bis in idem tidak diterapkan karena masih dalam proses kasasi ketika para pihak mengajukan gugatan ke pengadilan negeri.

\section{DAFTAR PUSTAKA}

Alim, M. (2013). Beberapa perlakuan diskriminatif terhadap peradilan agama. Varia Peradilan, $335,37-42$.

Anshoruddin, et al. (2016). Teknik pemeriksaan perkara gugat waris bagi hakim pengadilan agama. Cetakan I. Yogyakarta: UII Press.

Dirjen Badilag. (2014). Pedoman pelaksanaan tugas \& administrasi peradilan agama. Jakarta: Dirjen Badilag.
(2015). Himpunan peraturan perundang-undangan di lingkungan peradilan agama. Jakarta: Dirjen Badilag.

Ibrahim, M. Y. (2014). Impelentasi asas ne bis in idem dalam perkara yang telah memiliki kekuatan hukum tetap yang digugat kembali dengan sengketa objek yang sama tetapi subjek yang berbeda. Diakses dari https://jurnal.unars.ac.id/ artikel/2014-09-19.

Islamey, C. et al. (2012). Asas ne bis in idem. Diakses dari https://0imfh2013.files.wordpres. com/2014/08.

Kamil, A. (2016). Filsafat kebebasan hakim. Cetakan II. Jakarta: Predanamedia Group.

Manan, B. (2015). Penafsiran \& konstruksi hukum terhadap undang-undang dalam lingkungan peradilan agama di Perancis. Varia Peradilan, $355,7-30$

Manan, H.A. (2001). Penerapan hukum acara perdata di lingkungan peradilan agama. Cetakan II. Jakarta: Yayasan Al-Hikmah.

Mappiasse, S. (2015). Logika hukum pertimbangan hakim. Jakarta: Prenadamedia Group.

Nessa, R. et al. (2016). Membumikan hukum acara peradilan agama di Indonesia. Cetakan I. Jakarta: UII Press.

Qohar, A. et al. (2011). Hukum kewarisan Islam, keadilan \& metode praktis penyelesaiannya. Cetakan I. Yogyakarta: Pustaka Biru.

Ramulyo, I. (1992). Perbandingan hukum kewarisan Islam di pengadilan agama \& kewarisan menurut Undang-Undang Hukum Perdata $(B W)$ di pengadilan negeri. Cetakan I. Jakarta: Pedoman Ilmu Jaya.

Wirhanuddin. (2014). Mediasi perspektif hukum Islam. Semarang: Fatawa Publishing. 